medRxiv preprint doi: https://doi.org/10.1101/2021.08.03.21261414; this version posted August 4, 2021. The copyright holder for this preprint (which was not certified by peer review) is the author/funder, who has granted medRxiv a license to display the preprint in perpetuity.

It is made available under a CC-BY-ND 4.0 International license.

\title{
Azithromycin in patients with Covid-19; a systematic review and metanalysis
}

\section{Running title: Azithromycin for Covid-19}

Luis Ayerbe ${ }^{1,2}$, Ivo Forgone ${ }^{3}$, Carlos Risco-Risco ${ }^{4}$, Maria Pérez-Piñar ${ }^{2}$, Salma Ayis ${ }^{5}$

1- Centre of Primary Care and Mental Health, Queen Mary University of London, London, UK

2- Carnarvon Medical Centre. Southend on Sea UK

3- Canal de Panama Primary Care Centre, Madrid, Spain

4- Department of Internal Medicine. Sanchinarro HM University Hospital, Madrid, Spain

5- School of Population Health and Environmental Sciences, King's College London, London, UK

\section{Correspondence to:}

Luis Ayerbe

Centre of Primary Care and Mental Health, Queen Mary University of London, UK

Yvonne Carter Building

58 Turner Street

London E1 2AB 
medRxiv preprint doi: https://doi.org/10.1101/2021.08.03.21261414; this version posted August 4, 2021. The copyright holder for this preprint (which was not certified by peer review) is the author/funder, who has granted medRxiv a license to display the preprint in perpetuity.

It is made available under a CC-BY-ND 4.0 International license .

\begin{abstract}
Background: Azithromycin (AZM) has been widely used in the management of Covid-19.

However, the evidence on its actual effects remains disperse and difficult to apply in clinical settings. This systematic review and metanalysis summarizes the available evidence to date on the beneficial and adverse effect of AZM in patients with Covid-19.

Methods: The PRISMA 2020 statement criteria were followed. Randomized controlled trials (RCTs) and observational studies comparing clinical outcomes of patients treated, and not treated, with AZM, indexed until the $5^{\text {th }}$ of July 2021, were searched in PubMed, Embase, The Web of Science, Scopus, The Cochrane Central Register of Controlled Trials, and MedRXivs. We used Random-effects models to estimate pooled effect size from aggregate data.

Results: The initial search produced 4950 results. Finally, 16 studies, five RCTs and 11 with an observational design, with a total of 22984 patients, were included. The metanalysis showed no difference in mortality for those treated, or not, with AZM, OR: 0.95 (0.79-1.13). There was also no significant difference for those treated, and not, with AZM in need for hospital admission or time to admission from ambulatory settings, clinical severity, need for intensive care, or adverse effects.
\end{abstract}

Conclusions: These results presented in this review do not support the use of AZM in the management of Covid-19. They also show that any harm caused to the patient who received it is unlikely. Future research on treatment for patients with Covid-19 may need to focus on other drugs. 
medRxiv preprint doi: https://doi.org/10.1101/2021.08.03.21261414; this version posted August 4, 2021. The copyright holder for this preprint (which was not certified by peer review) is the author/funder, who has granted medRxiv a license to display the preprint in perpetuity.

It is made available under a CC-BY-ND 4.0 International license .

\section{Introduction}

Azithromycin (AZM) has been widely used in the management of Covid-19. ${ }^{1,2}$ It is a broadspectrum antibiotic, which is rapidly absorbed after oral intake, and has a long half-life.

Evidence suggests that AZM has antiviral activity in bronchial epithelial cells, together with antiinflammatory and immunoregulatory effects. ${ }^{1,2}$ The association of AZM with improved outcome in patients with other viral pneumonias, and in those with acute lung injury admitted in intensive care, has also been reported. ${ }^{2}$ The possible beneficial effect of AZM in patients with Covid-19 and bacterial superinfection has been considered as well. ${ }^{1}$ It is an economical drug that can be used in early stages of Covid-19. However, the possible QT-prolongation and cardiotoxicity associated with AZM are a concern. ${ }^{1-4}$

A number of individual studies have investigated the effect of AZM on different clinical outcomes among patients with Covid-19. The reviews where these articles are summarized are either narrative, they focus on the effect of AZM in combination with hydroxychloroquine, or are restricted to studies with a particular design. Therefore, the evidence on the actual beneficial or harmful effect of AZM in patients with Covid-19 remains disperse and difficult to apply in clinical settings. ${ }^{1}$ This systematic review and metanalysis summarizes the evidence on the beneficial and adverse effect of AZM in patients with Covid-19.

\section{Methods}

This systematic review and metanalysis was registered in the International prospective register of systematic reviews (PROSPERO) with the reference CRD 42021252219, and it was conducted following the PRISMA 2020 statement criteria. ${ }^{5,6}$ Randomized controlled trials and observational studies comparing clinical outcomes of patients treated, and not treated, with 
medRxiv preprint doi: https://doi.org/10.1101/2021.08.03.21261414; this version posted August 4, 2021. The copyright holder for this preprint (which was not certified by peer review) is the author/funder, who has granted medRxiv a license to display the preprint in perpetuity.

It is made available under a CC-BY-ND 4.0 International license .

AZM, were searched and considered for inclusion. All the publications indexed up to the $5^{\text {th }}$ of July 2021, in the following six databases were reviewed: PubMed, Embase, The Web of Science, Scopus, The Cochrane Central Register of Controlled Trials (CENTRAL), and MedRXivs. The following search strategy was used: (("Azithromycin"[Mesh]) OR "Macrolides"[Mesh]) AND ((("Coronavirus"[Mesh]) OR "COVID-19"[Mesh]) OR "SARS-CoV-2"[Mesh]) Studies in the bibliography of all the relevant reviews identified in the initial search were also considered for inclusion. The forward citation tool in the Web of Science was used and all papers that cited those included in the review were also considered for inclusion. There were no restrictions on the basis of language, sample size or duration of follow-up. Studies were not included in the following cases: they reported outcomes of specific participants i.e: cancer patients only; there was no comparison arm; azithromycin was compared against an intervention different to placebo or standard care; the effect of azithromycin in combination with another drug was the objective of the study; the exposure was not specifically azithromycin i.e: antibiotics, macrolides; the study had an observational design but no multivariate analysis, with adjustment for potential confounders, had been conducted.

Where several articles reported results from the same population, data were taken from the publication with the longest follow-up. The quality of all studies was assessed according to accepted criteria. ${ }^{7}$ Authors of studies were contacted when it was unclear whether papers met the inclusion criteria, and to verify methods and results that may not have been reported.

We used Random-effects models to estimate pooled effect size from aggregate data. ${ }^{8}$ The majority of the studies, provided estimates on the risk of death, Odds Ratios (ORs), Relative Risk (RRs), or Hazard Ratios (HRs). We pooled these using ORs, where RRs were transformed to ORs, and HRs were used as proxy measures for ORs as the percentage of the outcome was 
relatively small and the follow up period was short. ${ }^{9}$ When an RCT did not report a summary estimate, but provided numbers of deaths in each exposure group, the OR was calculated and used in the pooled summary estimates. When observational studies did not provide numerical measures of effect for death, they could not be included in the metanalysis and their results are presented narratively. Observational studies, and RCTs were displayed in one forest plot stratified by study design.

The summaries for outcomes other than death were reported narratively, due to the different methods used across studies and the small number of studies that investigated each outcome. Between-study heterogeneity was assessed using $\mathrm{I}^{2}$ statistics, which describes the percentage of variation across studies that is due to heterogeneity rather than chance. ${ }^{11}$ Publication bias was assessed visually using funnel plots and the Egger test was used to measure the small study effect. Statistical analysis was performed using the software STATA V.16.

\section{Results}

The initial search produced 4950 results, seven of them were reviews relevant to this topic. . $^{12-17}$ The full text of 35 articles was assessed. Finally, our review included 16 studies, with a total of 22984 patients. ${ }^{18-33}$ The studies assessed in each stage of the search are presented in supplement one. Five of the studies were randomized controlled trials and 11 had an observational design. They had been conducted in Brazil, France, Italy, Iran, Spain, Turkey, the UK, and the USA. Four studies had been conducted in ambulatory settings, 11 in hospitals, and one included both hospital and ambulatory patients. The sample size ranged from 111 to $7763{ }^{18,19}$ patients. The characteristics of the studies included in this review are presented in tables one and two. 


\begin{tabular}{|c|c|c|c|c|c|}
\hline $\begin{array}{l}\text { Author. } \\
\text { Country }\end{array}$ & $\begin{array}{l}\text { Settin } \\
\mathrm{g}\end{array}$ & $\begin{array}{l}\mathrm{N} \\
\text { AZM/comparion }\end{array}$ & Outcome & $\begin{array}{l}\text { Outcome } \mathrm{n} \\
\text { AZM/Comparison }\end{array}$ & Effect \\
\hline \multirow[t]{5}{*}{$\begin{array}{l}\text { Furtado - } \\
\text { Brazil } \\
2020\end{array}$} & \multirow[t]{5}{*}{ Hosp } & \multirow[t]{5}{*}{$214 / 183$} & $\begin{array}{l}\text { Higher category } \\
\text { of clinical status } \\
\text { score }\end{array}$ & & $\begin{array}{l}\text { Clinical status:1.36(0.94- } \\
1.97)\end{array}$ \\
\hline & & & Death & $90 / 73$ & $\begin{array}{l}\text { Death } 1.08(0.79-1.47) \\
\mathrm{p}=0.63\end{array}$ \\
\hline & & & $\begin{array}{l}\text { Median duration } \\
\text { of admission } \\
\text { (days) }\end{array}$ & $26 / 18$ & $\begin{array}{l}\text { Median Difference } 8.00 \\
(0.81-15.19) \quad p=0.064\end{array}$ \\
\hline & & & $\begin{array}{l}\text { Serious adverse } \\
\text { events }\end{array}$ & $102 / 75$ & $\begin{array}{l}\text { No difference in adverse } \\
\text { events } p=0.35\end{array}$ \\
\hline & & & QT prolongation & $47 / 42$ & $\begin{array}{l}\text { No difference. } \\
\text { No differnce in ventricular } \\
\text { arrythmia or need for } \\
\text { resucitation }\end{array}$ \\
\hline \multirow[t]{3}{*}{$\begin{array}{l}\text { Hinks } \\
2021 \mathrm{UK}\end{array}$} & \multirow[t]{3}{*}{$\begin{array}{l}\text { Com } \\
\mathrm{m}\end{array}$} & \multirow[t]{3}{*}{$147 / 148$} & $\begin{array}{l}\text { Death or need for } \\
\text { admission }\end{array}$ & $15 / 17$ & OR: $0.91(0.43-1.92) \mathrm{p}=0.80$ \\
\hline & & & $\begin{array}{l}\text { Time to } \\
\text { admission }\end{array}$ & & HR:0.95(0.46-1.96)p=0.89 \\
\hline & & & $\begin{array}{l}\text { Maximum } \\
\text { clinical severity }\end{array}$ & & OR: $0.91(0.57-1.46) \mathrm{p}=0.69$ \\
\hline \multirow{3}{*}{$\begin{array}{l}\text { PRINCIP } \\
\text { LE } 2021 \\
\text { UK }\end{array}$} & \multirow[t]{3}{*}{$\begin{array}{l}\text { Com } \\
\mathrm{m}\end{array}$} & \multirow[t]{3}{*}{$540 / 875$} & $\begin{array}{l}\text { Clinical recovery } \\
\text { day } 28\end{array}$ & $402 / 631$ & \\
\hline & & & $\begin{array}{l}\text { Time to clinical } \\
\text { recovery }\end{array}$ & & HR: $1.08(0.95-1.23)$ \\
\hline & & & $\begin{array}{l}\text { Need for } \\
\text { Admission }\end{array}$ & $16 / 28$ & Difference: $0.3(-1.7-2.2)$ \\
\hline \multirow[t]{5}{*}{$\begin{array}{l}\text { RECOVE } \\
\text { RY } \\
\text { UK } \\
2021\end{array}$} & \multirow[t]{5}{*}{ Hosp } & \multirow[t]{5}{*}{$2582 / 5181$} & Death & $561 / 1162$ & $\begin{array}{l}\text { RR: } 0.97(0.87-1.107) \\
\mathrm{p}=0.50 \\
\text { This result was also not } \\
\text { significant in differnet age } \\
\text { or gender ctegories }\end{array}$ \\
\hline & & & $\begin{array}{l}\text { Median duration } \\
\text { of admission } \\
\text { (days) }\end{array}$ & $10 / 11$ & \\
\hline & & & $\begin{array}{l}\text { Discharged alive } \\
\text { on day } 28(\%)\end{array}$ & $68 / 69$ & RR: $1.04(0.98-1.10) \mathrm{p}=0.19$ \\
\hline & & & $\begin{array}{l}\text { Need for } \\
\text { mechanical } \\
\text { vnetilation or } \\
\text { death }(\%) \\
\end{array}$ & $25 / 26$ & RR: $0.95(0.87-1.03) \mathrm{p}=0.24$ \\
\hline & & & $\begin{array}{l}\text { Serious adverse } \\
\text { events }\end{array}$ & $1 / 0$ & No difference in arrythmias \\
\hline \multirow[t]{4}{*}{$\begin{array}{l}\text { Sekhavati } \\
\text { Iran } \\
2020\end{array}$} & \multirow[t]{4}{*}{ Hosp } & \multirow[t]{4}{*}{$56 / 55$} & $\begin{array}{l}\text { Durarion of } \\
\text { admission } \\
\text { (Mean?days) } \\
\end{array}$ & $4.61 / 5.96$ & $\mathrm{P}=0.02$ \\
\hline & & & Need for ICU & $2 / 7$ & $\mathrm{P}=0.070$ \\
\hline & & & Death & $0 / 1$ & $\mathrm{p}=0.495$ \\
\hline & & & & & $\begin{array}{l}\text { No differnece in QT } \\
\text { prolongation or arrythmia }\end{array}$ \\
\hline
\end{tabular}

Table 1. Randomised Controled Trials included in the review (Hosp: Hospital, Comm: Community) 
medRxiv preprint doi: https://doi.org/10.1101/2021.08.03.21261414; this version posted August 4, 2021. The copyright holder for this preprint (which was not certified by peer review) is the author/funder, who has granted medRxiv a license to display the preprint in perpetuity.

It is made available under a CC-BY-ND 4.0 International license .

\begin{tabular}{|c|c|c|c|c|c|}
\hline $\begin{array}{l}\text { Author } \\
\text { year } \\
\text { Country }\end{array}$ & $\begin{array}{l}\text { Settin } \\
\mathrm{g}\end{array}$ & $\begin{array}{l}\mathrm{N} \\
\mathrm{AZM} / \text { Comparison }\end{array}$ & Otcome & $\begin{array}{l}\text { Outcome } n \\
\text { AZM/Comparison }\end{array}$ & Effect \\
\hline \multirow{3}{*}{$\begin{array}{l}\text { Albani } \\
2020 \\
\text { Italy }\end{array}$} & \multirow[t]{3}{*}{ Hosp } & \multirow[t]{3}{*}{$421 / 605$} & Death & $69 / 172$ & OR $0.60(0.42-0.85)$ \\
\hline & & & Need for ICU & $20 / 46$ & OR: $1.08(0.57-2.05)$ \\
\hline & & & $\begin{array}{l}\text { Median Duration } \\
\text { of admission } \\
\text { (days) }\end{array}$ & $6 / 6$ & OR: $1.17(1.10-1.25)$ \\
\hline $\begin{array}{l}\text { Arshad } \\
2020 \text { USA }\end{array}$ & Hosp & $147 / 409$ & Death & $33 / 108$ & HR: $1.050(0.682-1.616)$ \\
\hline $\begin{array}{l}\text { Ayerbe } \\
2020 \\
\text { Spain }\end{array}$ & Hosp & $1223 / 796$ & Death & $146 / 140$ & OR: $0.53(0.19-1.50) \mathrm{p}=0.233$ \\
\hline \multirow[t]{2}{*}{$\begin{array}{l}\text { Guérin } \\
2020 \\
\text { France }\end{array}$} & \multirow[t]{2}{*}{$\begin{array}{l}\text { Com } \\
\mathrm{m}\end{array}$} & \multirow[t]{2}{*}{$34 / 34$} & $\begin{array}{l}\text { Time to clinical } \\
\text { revcovery } \\
\text { (days) }\end{array}$ & $12.9 / 25.8$ & \multirow{2}{*}{$\begin{array}{l}(\mathrm{P}=0.0149) \\
\text { No serious adverse event } \\
\text { neither cardiovascular } \\
\text { events were reported in any } \\
\text { treatment group. }\end{array}$} \\
\hline & & & Need for ICU & $8 / 1$ & \\
\hline \multirow{2}{*}{$\begin{array}{l}\text { Ip } \\
2020 \\
\text { USA }\end{array}$} & \multirow[t]{2}{*}{ Hosp } & \multirow[t]{2}{*}{$256 / 2256$} & Death & & HR: $0.89(0.72-1.10) \mathrm{p}=0.28$ \\
\hline & & & $\begin{array}{l}\text { Duration of } \\
\text { admission }\end{array}$ & & HR: $1.45(0.88-2.41) \mathrm{p}=0.150$ \\
\hline $\begin{array}{l}\text { Kokturk } \\
2021 \\
\text { Turkey }\end{array}$ & Hosp & $738 / 762$ & Death & $34 / 33$ & OR: $1.54(0.48-4.98) \mathrm{p}=0.472$ \\
\hline $\begin{array}{l}\text { Pathak } \\
2021 \text { USA }\end{array}$ & Hosp & & $\begin{array}{l}\text { Need for ICU } \\
\text { ICU death }\end{array}$ & & $\begin{array}{l}\text { No association between AZM } \\
\text { and the outcomes }\end{array}$ \\
\hline \multirow{2}{*}{$\begin{array}{l}\text { Rodriguez } \\
\text {-Molinero } \\
2020 \\
\text { Spain } \\
\end{array}$} & \multirow[t]{2}{*}{ Hosp } & \multirow[t]{2}{*}{$120 / 63$} & Death & $7 / 6$ & $\mathrm{P}=0.501$ \\
\hline & & & $\begin{array}{l}\text { Duration of } \\
\text { admission }\end{array}$ & & HR: $1.45(0.88-2.41) \mathrm{p}=0.150$ \\
\hline \multirow{3}{*}{$\begin{array}{l}\text { Rosenberg } \\
2020 \\
\text { USA }\end{array}$} & \multirow[t]{3}{*}{ Hosp } & \multirow[t]{3}{*}{$121 / 211$} & Death & $21 / 28$ & HR: $0.56(0.26-1.21)$ \\
\hline & & & Cardiac arrest & $5 / 7$ & HR: $0.64(0.27-1.56)$ \\
\hline & & & Abnormal ECG & & HR: $0.95(0.47-1.94)$ \\
\hline $\begin{array}{l}\text { Szente- } \\
\text { Fonseca } \\
2020 \\
\text { Brazil } \\
\end{array}$ & $\begin{array}{l}\text { Com } \\
\mathrm{m}\end{array}$ & $380 / 337$ & $\begin{array}{l}\text { Need for } \\
\text { Admissions (114) }\end{array}$ & & $0.93(0.60-1.45)$ \\
\hline $\begin{array}{l}\text { Wang } \\
2020 \\
\text { USA } \\
\end{array}$ & $\begin{array}{l}\text { Hosp } \\
\text { and } \\
\text { comm } \\
\end{array}$ & $535 / 4165$ & Death & $124 / 168$ & OR: $1.57(1.14-2.16) \mathrm{p}=0.006$ \\
\hline
\end{tabular}

Table 2 Observational studies included in the review (Hosp: Hospital, Comm: Community)

The dose of azithromycin was reported in 11 studies. In four of them patients received $500 \mathrm{mg}$ a day for 5 days. ${ }^{19-22}$ Patients were given $500 \mathrm{mg}$ on the first day, and then $250 \mathrm{mg}$ a day the following four days, in three studies. ${ }^{23-25}$ In two studies patients were treated with $500 \mathrm{mg}$ a day 
for ten days. ${ }^{18,26}$ In one study patients received $500 \mathrm{mg}$ a day for 14 days ${ }^{27}$ and in another one $500 \mathrm{mg}$ a day for 3 days. $^{28}$

Death was the outcome in 13 studies, duration of hospital admission in six, need for intensive care unit (ICU) in four, and need for admission in two. Other secondary outcomes were also reported in individual studies. Tables one and two present the outcomes reported in each study. The quality of the studies was considered good in 15 studies, and limited in one where only an abstract was available. (Supplements 2 and 3)

The metanalysis showed no difference in death for those treated, or not, with AZM, in observational studies OR: 0.90 (0.66-1.24), RCTs, OR: 0.97 (0.87-1.08), and when studies with both designs were pooled together OR: 0.95 (0.79-1.13). (Figure 1) In the study by Hinks and colleagues $^{27}$ the outcome was death or need for admission, and this was used as a proxy for death in the metanalysis. Excluding this study had minimal effect on the magnitude and the significance of the results, with an overall OR: $0.95(0.79-1.14)$. Two further observational studies that did not present measure of effect, and could not be included in the metanalysis, reported narratively no evidence of association between treatment with AZM and death. ${ }^{24,29}$ Three observational studies and one RCT reported no association between the use of AZM and the duration of hospital admission, ${ }^{20,24,26,31}$ while another RCT showed evidence of hospital admission shorter by one day for those who received AZM. ${ }^{19}$ The two observational studies and the two RCTs, that had need for ICU as an outcome, reported it not to be associated with AZM. ${ }^{18,19,20,29}$ One observational study and one RCT, conducted both in the community, reported no association between treatment with AZM and need for admission. ${ }^{22,28}$ 
medRxiv preprint doi: https://doi.org/10.1101/2021.08.03.21261414; this version posted August 4, 2021. The copyright holder for this preprint (which was not certified by peer review) is the author/funder, who has granted medRxiv a license to display the preprint in perpetuity.

It is made available under a CC-BY-ND 4.0 International license.

AZM was not associated with serious adverse events, ${ }^{18,26}$ QT prolongation, ${ }^{19,26,30}$ arrythmia, ${ }^{18,19,26}$ or need for resuscitation. ${ }^{26,30}$ (Tables 1 and 2) The reasonably symmetrical funnel plot supports the theory that there is no publication bias. (Supplement 4)

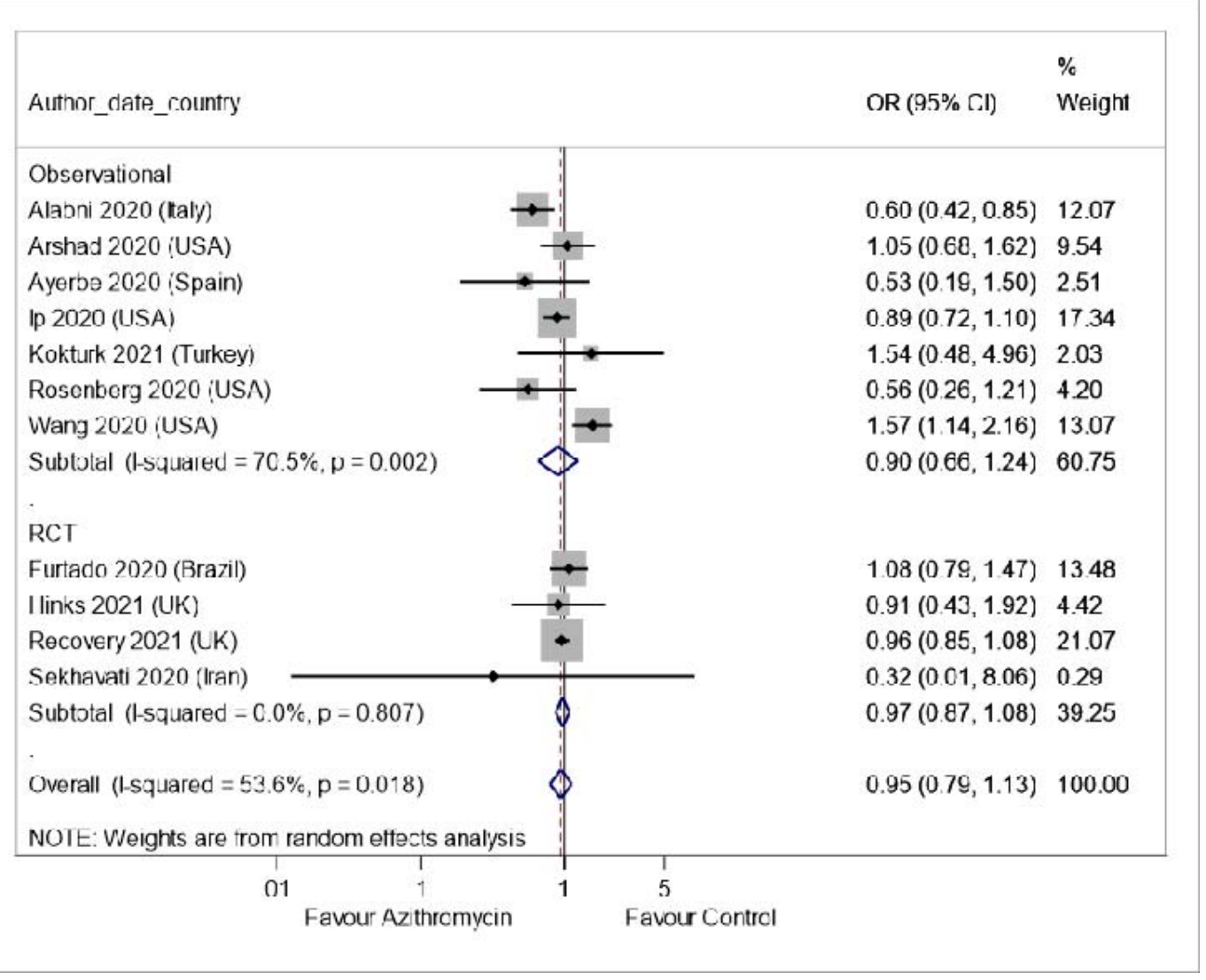

Figure 1. Forest plot of Observational studies and RCTs on the association between treatment with AZM and death

\section{Discussion}

This systematic review and metanalysis presents strong evidence on the lack of association between AZM and any clinical benefit. ${ }^{34}$ This evidence is consistent across 16 studies conducted 
medRxiv preprint doi: https://doi.org/10.1101/2021.08.03.21261414; this version posted August 4, 2021. The copyright holder for this preprint (which was not certified by peer review) is the author/funder, who has granted medRxiv a license to display the preprint in perpetuity.

It is made available under a CC-BY-ND 4.0 International license .

in Europe, America and Asia with diverse methodology and design. There is also no evidence of AZM being associated with any serious adverse events, including cardiovascular disease.

This review has some limitations. Only one person extracted most of the data (LA). Even so, all data were checked for accuracy on repeated occasions and all analyses were conducted several times and checked by a senior statistician (SA). It is also possible that some publications may have been missed. The use of standard care, provided in addition to AZM in the intervention arm, and on its own in the comparison arm, was not described in detail in some studies. It is not clear how different this standard care was across the studies and how this may have affected the results. Some RCTs adjusted the treatment effect for confounders but not all did so. In those adjusted however, there was no considerable difference between the unadjusted and adjusted estimates, likely due to the balanced characteristics of the compared groups, achieved by randomization.

The comprehensive search in six databases, and critical assessment of 16 studies, that added together a large number of patients, represent strengths of this review. The inclusion of both observational and interventional studies, based in different settings and looking at various outcomes, are also positive aspects of this research. Furthermore, the sensitivity analyses that was conducted adds consistency to the results. The use of a random effect model was a conservative choice. The overall estimate remained significant despite the increased width of the confidence intervals, providing support to the significance of the findings.

The results presented in this review do not support the use of AZM in the management of Covid19. They also show that any harm caused to patients who received it is unlikely, which would be consistent with the well stablished safety profile reported before for AZM. ${ }^{4}$ Future research on 
medRxiv preprint doi: https://doi.org/10.1101/2021.08.03.21261414; this version posted August 4, 2021. The copyright holder for this preprint (which was not certified by peer review) is the author/funder, who has granted medRxiv a license to display the preprint in perpetuity. It is made available under a CC-BY-ND 4.0 International license.

repurposed or innovative treatment for patients with Covid-19 may need to consider alternative drugs.

\section{Funding:}

This study was funded by a grant from the Claire Wand Fund

Salma Ayis was funded by the National Institute for Health Research (NIHR) Biomedical Research Centre based at Guy's and St Thomas' NHS Foundation Trust and King's College London. The views expressed are those of the authors and not necessarily those of the NHS, the NIHR, or the Department of Health.

Transparency declarations: Authors have no interests to declare Authors contributions: LA had the original idea, that then received input from IF, CRR, MPP and SA. LA conducted the searches. IF and MPP assessed the quality of the studies. LA and SA extracted the data. SA conducted the statistical analyses. LA wrote the first draft, that was later amended with contributions and references provided by IF, CRR, MPP and SA. 
medRxiv preprint doi: https://doi.org/10.1101/2021.08.03.21261414; this version posted August 4, 2021. The copyright holder for this preprint (which was not certified by peer review) is the author/funder, who has granted medRxiv a license to display the preprint in perpetuity.

It is made available under a CC-BY-ND 4.0 International license .

\section{Reeferences}

1. Sultana J, Cutroneo PM, Crisafulli S, Puglisi G, Caramori G, Trifirò G. Azithromycin in COVID-19 Patients: Pharmacological Mechanism, Clinical Evidence and Prescribing Guidelines. Drug Saf. Aug 2020;43(8):691-698. doi:10.1007/s40264-020-00976-7

2. Gyselinck I, Janssens W, Verhamme P, Vos R. Rationale for azithromycin in COVID-19: an overview of existing evidence. BMJ Open Respir Res. Jan 2021;8(1)doi:10.1136/bmjresp2020-000806

3. O'Connell TF, Bradley CJ, Abbas AE, et al. Hydroxychloroquine/Azithromycin Therapy and QT Prolongation in Hospitalized Patients With COVID-19. JACC Clin Electrophysiol. Jan 2021;7(1):16-25. doi:10.1016/j.jacep.2020.07.016

4. Parnham MJ, Erakovic Haber V, Giamarellos-Bourboulis EJ, Perletti G, Verleden GM, Vos R. Azithromycin: mechanisms of action and their relevance for clinical applications.

Pharmacol Ther. Aug 2014;143(2):225-45. doi:10.1016/j.pharmthera.2014.03.003

5. PROSPEROI International prospective register of systematic reviews. https://www.crd.york.ac.uk/PROSPERO/

6. Preferred Reporting Items for Systematic Reviews and Meta-Analyses (PRISMA). http://www.prisma-statement.org/

7. SIGN. Methodology assessment. https://www.sign.ac.uk/what-wedo/methodology/checklists/

8. DerSimonian R, Kacker R. Random-effects model for meta-analysis of clinical trials: an update. Contemp Clin Trials. Feb 2007;28(2):105-14. doi:10.1016/j.cct.2006.04.004

9. Spruance SL, Reid JE, Grace M, Samore M. Hazard ratio in clinical trials. Antimicrob Agents Chemother. Aug 2004;48(8):2787-92. doi:10.1128/aac.48.8.2787-2792.2004 
medRxiv preprint doi: https://doi.org/10.1101/2021.08.03.21261414; this version posted August 4, 2021. The copyright holder for this preprint (which was not certified by peer review) is the author/funder, who has granted medRxiv a license to display the preprint in perpetuity.

It is made available under a CC-BY-ND 4.0 International license .

10. Kiran A, Crespillo AP, Rahimi K. Graphics and Statistics for Cardiology: Data visualisation for meta-analysis. Heart. Jan 1 2017;103(1):19-23. doi:10.1136/heartjnl-2016309685

11. Higgins JP, Thompson SG. Quantifying heterogeneity in a meta-analysis. Stat Med. Jun 15 2002;21(11):1539-58. doi:10.1002/sim.1186

12. Fiolet T, Guihur A, Rebeaud M, Mulot M, Peiffer-Smadja N, Mahamat-Saleh Y. Effect of hydroxychloroquine with or without azithromycin on the mortality of COVID-19 patients: a systematic review and meta-analysis. Clin Microbiol Infect. Aug 21

2020;doi:10.1016/j.cmi.2020.08.022

13. Juul S, Nielsen EE, Feinberg J, et al. Interventions for treatment of COVID-19: A living systematic review with meta-analyses and trial sequential analyses (The LIVING Project). PLoS Med. Sep 2020;17(9):e1003293. doi:10.1371/journal.pmed.1003293

14. Kim MS, An MH, Kim WJ, Hwang TH. Comparative efficacy and safety of pharmacological interventions for the treatment of COVID-19: A systematic review and network meta-analysis. PLoS Med. Dec 2020;17(12):e1003501. doi:10.1371/journal.pmed.1003501

15. Lepere P, Escarguel B, Yolartiran S, Escarguel C. COVID-19: Can early home treatment with Azithromycin alone or with Zinc help prevent hospitalisation, death, and long-COVID-19? A review. https://www.medrxiv.org/content/10.1101/2020.12.29.20248975v2

16. Parra-Lara LG, Martínez-Arboleda JJ, Rosso F. Azithromycin and SARS-CoV-2 infection: Where we are now and where we are going. J Glob Antimicrob Resist. Sep 2020;22:680-684. doi:10.1016/j.jgar.2020.06.016 
medRxiv preprint doi: https://doi.org/10.1101/2021.08.03.21261414; this version posted August 4, 2021. The copyright holder for this preprint (which was not certified by peer review) is the author/funder, who has granted medRxiv a license to display the preprint in perpetuity. It is made available under a CC-BY-ND 4.0 International license .

17. Kamel, A. M. Monem, M. S. A. Sharaf, N. A. Magdy, N. Farid, S. F.. Efficacy and safety of azithromycin in Covid-19 patients: A systematic review and meta-analysis of randomized clinical trials. Rev Med Virol 2021 ;e2258. doi: 10.1002/rmv.2258

18. Azithromycin in patients admitted to hospital with COVID-19 (RECOVERY): a randomised, controlled, open-label, platform trial. Lancet. 2021;397(10274):605-612. doi:10.1016/s0140-6736(21)00149-5

19. Sekhavati E, Jafari F, SeyedAlinaghi S, et al. Safety and effectiveness of azithromycin in patients with COVID-19: An open-label randomised trial. Int J Antimicrob Agents. 2020;56(4):106143. doi:10.1016/j.ijantimicag.2020.106143

20. Albani F, Fusina F, Giovannini A, et al. Impact of Azithromycin and/or Hydroxychloroquine on Hospital Mortality in COVID-19. J Clin Med. Aug 30 2020;9(9)doi:10.3390/jcm9092800

21. Ayerbe L, Risco C, Ayis S. The association of treatment with hydroxychloroquine and hospital mortality in Covid-19 patients. Intern Emerg Med. 2020; 15(8):1501-1506

22. Nunes-Szente-Fonseca S, de- Queiroz-Sousa A, Giandoni-Wolkoff A, et al. Risk of hospitalization for Covid-19 outpatients treated with various drug regimens in Brazil:

Comparative analysis. Travel Medicine and Infectious Disease.

2020;doi:https://doi.org/10.1016/j.tmaid.2020.101906

23. Arshad S, Kilgore P, Chaudhry ZS, et al. Treatment with Hydroxychloroquine, Azithromycin, and Combination in Patients Hospitalized with COVID-19. International Journal of Infectious Diseases. 2020;doi:https://doi.org/10.1016/j.ijid.2020.06.099

24. Rodríguez-Molinero A, Pérez-López C, Gálvez-Barrón C, Miñarro A, Macho O, López GF, Robles MT, Dapena MD, Martínez S, Rodríguez E, Collado I; COVID-19 research group of 
medRxiv preprint doi: https://doi.org/10.1101/2021.08.03.21261414; this version posted August 4, 2021. The copyright holder for this preprint (which was not certified by peer review) is the author/funder, who has granted medRxiv a license to display the preprint in perpetuity.

It is made available under a CC-BY-ND 4.0 International license .

CSAPG.Observational study of azithromycin in hospitalized patients with COVID-19. PLoS

One. 2020 Sep 3;15(9):e0238681. doi: 10.1371/journal.pone.0238681. eCollection 2020.

25. Guérin V, Lévy P, Thomas J-L, et al. Azithromycin and Hydroxychloroquine Accelerate

Recovery of Outpatients with Mild/Moderate COVID-19. Asian J Med Health. 2020;18:45-5.

26. Furtado RHM, Berwanger O, Fonseca HA, et al. Azithromycin in addition to standard of care versus standard of care alone in the treatment of patients admitted to the hospital with severe COVID-19 in Brazil (COALITION II): a randomised clinical trial. Lancet. 2020;396(10256):959-967. doi:10.1016/s0140-6736(20)31862-6

27. Hinks T, Cureton L, Knight R, et al. A randomised clinical trial of azithromycin versus standard care in ambulatory COVID-19 - the ATOMIC2 trial. https://www.medrxiv.org/content/10.1101/2021.04.21.21255807v1

28. Azithromycin for community treatment of suspected COVID-19 in people at increased risk of an adverse clinical course in the UK (PRINCIPLE): a randomised, controlled, open-label, adaptive platform trial. Lancet. 2021;397(10279):1063-1074. doi:10.1016/s0140-

6736(21)00461-X

29. V. Pathak, C. Conklin. Predictors of ICU Admission and Mortality in Patients with Coronavirus Disease - 2019 (COVID 19) in Community Hospitals Am J Respir Crit Care Med 2021;203:A2551

30. Rosenberg E, Dufort E, Udo T, et al. Association of Treatment With Hydroxychloroquine or Azithromycin With In-Hospital Mortality in Patients With COVID-19 in New York State. 2020;doi:10.1001/jama.2020.8630

31. Ip A, Berry DA, Hansen E, Goy AH, Pecora AL, Sinclaire BA, Bednarz U, Marafelias M, Berry SM, Berry NS, Mathura S, Sawczuk IS, Biran N, Go RC, Sperber S, Piwoz JA, Balani B, 
medRxiv preprint doi: https://doi.org/10.1101/2021.08.03.21261414; this version posted August 4, 2021. The copyright holder for this preprint (which was not certified by peer review) is the author/funder, who has granted medRxiv a license to display the preprint in perpetuity. It is made available under a CC-BY-ND 4.0 International license .

Cicogna C, Sebti R, Zuckerman J, Rose KM, Tank L, Jacobs LG, Korcak J, Timmapuri SL, Underwood JP, Sugalski G, Barsky C, Varga DW, Asif A, Landolfi JC, Goldberg

SL.Hydroxychloroquine and tocilizumab therapy in COVID-19 patients-An observational study. PLoS One. 2020 Aug 13;15(8):e0237693. doi: 10.1371/journal.pone.0237693. eCollection 2020. 32. Kokturk N, Babayigit C, Kul S, Duru Cetinkaya P, Atis Nayci S, Argun Baris S, Karcioglu O, Aysert P, Irmak I, Akbas Yuksel A, Sekibag Y, Baydar Toprak O, Azak E, Mulamahmutoglu S, Cuhadaroglu C, Demirel A, Kerget B, Baran Ketencioglu B, Ozger HS, Ozkan G, Ture Z, Ergan B, Avkan Oguz V, Kilinc O, Ercelik M, Ulukavak Ciftci T, Alici O, Nurlu Temel E, Ataoglu O, Aydin A, Cetiner Bahcetepe D, Gullu YT, Fakili F, Deveci F, Kose N, Tor MM, Gunluoglu G, Altin S, Turgut T, Tuna T, Ozturk O, Dikensoy O, Yildiz Gulhan P, Basyigit I, Boyaci H, Oguzulgen IK, Borekci S, Gemicioglu B, Bayraktar F, Elbek O, Hanta I, Kuzu Okur H, Sagcan G, Uzun O, Akgun M, Altinisik G, Dursun B, Cakir Edis E, Gulhan E, Oner Eyuboglu F, Gultekin O, Havlucu Y, Ozkan M, Sakar Coskun A, Sayiner A, Kalyoncu AF, Itil O, Bayram H. The predictors of COVID-19 mortality in a nationwide cohort of Turkish patients. Respir Med. 2021 Jul;183:106433. doi: 10.1016/j.rmed.2021.106433.

33 An-Li Wang, PhD1,2; Xiaobo Zhong, DrPH4,5; Yasmin L Hurd, PhD Comorbidity and Sociodemographic determinants in COVID-19 Mortality in an US Urban Healthcare System medRxiv preprint doi: https://doi.org/10.1101/2020.06.11.20128926

34. OCEBM Levels of Evidence Working Group. "The Oxford 2011 Levels of Evidence". Oxford Centre for Evidence-Based Medicine. http://www.cebm.net/index.aspx?o=5653 